\title{
Analysis of Community Satisfaction Survey Results to Improve the Quality of Service in the Sa'dan District
}

\author{
Elisabet Pali \\ Indonesian Toraja Christian University
}

\begin{abstract}
The purpose of this study was to analyze community satisfaction surveys in Sa'dan District, North Toraja Regency. The method of this research is descriptive research method through a qualitative approach. The sampling technique used was an incidental sampling technique with a sample of 250 people who had received services at the Sa'dan District Office. Data collection techniques used were questionnaires, observation and documentation, while the technique of data analysis used descriptive quantitative. The results showed that out of nine elements of existing services in the district as a whole can be categorized Sa'dan unfavorable. Nine elements of service have two elements in the good category, namely servant competence and servant behavior. The seven elements of the unfavorable category is the service requirements, procedures, time of service, discipline, product specification services, complaint handling, and facilities and infrastructure. Furthermore, the results of these studies followed by Importance Performance Analysis (IPA) diagram to determine the position and priority repairs of each element of the service provided. The results of the IPA diagram show that some things should have top priority in improving services such as: Service Time, Complaint Handling, Facilities and Infrastructure, Service Requirements, Discipline.Other than, there are two services that need to be maintained, namely Implementing Behavior and Waiter Competence, and services that are considered to have a low priority for improvement are elements of Product Service Specifications, Service Procedures.
\end{abstract}

Keywords: community satisfaction, element of service

DOI: $10.7176 / \mathrm{IKM} / 9-6-01$

Publication date:June $30^{\text {th }} 2019$

\section{Introduction}

1.1 Background

Quality public services is the hope of all the people. Public service not only to the fulfillment of public needs, but more than that the implementation of public service excellence. Fulfillment of public service is a requirement of the government bureaucracy reform that requires creative and innovative thinking with real action from time to time, with the aim of increasing the quality of public services to the community. The local government has a responsibility to meet the needs of a sustainable society through improved quality of service to the community realize the satisfaction of the appropriate authority owned. Efforts to improve the performance of public services be approached from two sides. First, the government as a provider of services, and both sides of the community as a service user perspective. This is based on the idea that providing services is a government obligation. Therefore, to improve the quality of services the government needs to make improvements, increase service management. One of the activities of government offices providing public services to the community is the Sa'dan district office. Sa'dan district office is one of the offices that provide administrative services are located in North Toraja district, a form of service rendered there are nine service requirements, procedures, time of service, discipline, product specification services, competence waiters, waitresses behavior, handling of complaints , and facilities and infrastructure.

To achieve quality public services, carried out Community Satisfaction Survey (CSS). CSS results will be used as basis to improve management of public services, where the improvement, the increase is expected to produce services that meet the expectations of the society. In this paper there are three things to be achieved from implementation of CSS: 1) as a guide to measure changes in Value Satisfaction Society in the following year; 2) map the performance of the Public Service Unit in the district Sa'dan as a reflection of the performance of public services in the district Sa'dan perceived by service users or the public; and 3) identify the Hope Society will public services in North Toraja Regency. The evaluation will provide an overview of the elements of what services are a top priority to be fixed, improved, which should be maintained, and the elements of what services are already exceeding the expectations of society. Thus, the results of this CSS will help Sa'dan district, to determine the proposed service improvement with priority scale. Repairs and upgrades to the priorities, will make resources such as power, money, and power can be used effectively and efficiently.

\subsection{Definition of Public Service}

Public service is defined as a form of services in the form of public goods and public services. According to Kotler (2009: 4-5), the service is any activity that is beneficial in a group or entity, and offers a satisfaction even though the results are not tied to a physical product. The scope includes education, teaching, employment and 
business, shelter, communication and information, environment, health, social security, energy, banking, transportation, natural resources, tourism, and other strategic sectors. Based on the above it can be concluded that the essence of public service is providing excellent service to the community. It is a manifestation of the role and functions of the state apparatus as a public servant.

\subsection{Types of Public Services}

Decree of the Minister of Administrative Reform No. 63 yaers 2004 about the General Guidelines for the Implementation of Public Service, classify three types of services from government agencies and state-owned companies/enterprises that are based on the characteristics and nature of activities and services produced products. The three types of services from government agencies and state-owned companies/enterprises are as follows: a) Administrative Services is the type of service provided by the service unit in the form of record keeping, research, decision making, documentation and administrative activities more overall yield of the final product in the form of documents, for example certificates, licenses, recommendations and so forth. b) Goods Services are provided in the form of service provision activities and physical or tangible goods processing, including the distribution and delivery to consumers directly (as a unit or individual) in a system. These activities resulted in a final product tangible object (physical) example electricity, water and telephone services, and c) Services are the type of services provided by the service unit form and supporting facilities and infrastructure. The final product is a service that brings benefits to the recipient directly and is used up within a certain period of time. For example, banking services, postal services and fire-fighting services. From the description above, it can be concluded that there are several types of public services provided by the government to the public. In general there are three types of services, namely administrative services, goods services, and service services. Based on the three types of the services to be examined in the survey are included into the category of administrative services and services.

\subsection{Factors Affecting Public Services}

Good service will finally give satisfaction to the people and improve the image of the organization so that the organization's image in the eyes of society increases. Increased image of the organization in this case the government will increase public confidence, where it became one of the main goals of the development of good governance (good governance). According to Kasmir (2005: 3), the main factors that influence service are employee resources. This means that the role of manumur (employees) who serve the community is a major factor because only by grooming customers can communicate directly and openly. The Decree of the Minister of Administrative Reform Number 63 of 2003 concerning General Guidelines for the Implementation of Public Services, states that the implementation of public services must meet several principles, namely:

a. Simplicity (service procedures are not convoluted, easy to understand and easy to implement);

b. Clarity (clarity covers in terms of technical requirements and administrative services, work units and the responsible authorities in providing services and settlement of complaints, details of the service charge and procedure for the organization);

c. Certainty of time (the service implementation can be completed within a predetermined time),

d. Accuracy (product of service is received correctly, proper and valid);

e. Security (process and product services to provide security and legal certainty);

f. Responsibility (leadership service providers are responsible for the provision of services and resolution of complaints / problems in the implementation of the service);

g. Completeness of infrastructure (availability of infrastructure, adequate work includes the provision of telecommunications and information technology);

h. Ease of access (the place and the location and service facilities adequate and accessible society);

i. Discipline, courtesy and friendliness (giving service must be disciplined, polite and polite, friendly and provide service sincerely);

j. Convenience (the service environment should be orderly, organized, comfortable, clean, tidy, beautiful environment and healthy, and are equipped with supporting facilities services, such as parking, restrooms, places of worship, etc.)

Based on the description above, it can be concluded that in assessing or measuring the quality of services can use many dimensions of measurement such as performance, product uniformity, suitability, ability to serve, reliability, responsiveness, comfort, security and completeness of infrastructure. Dimensions of service quality can be used as a reference to see the quality of services provided North Toraja regency administration of some aspects in it. One of the usefulness of the service dimension, as a tool to identify gaps between the expected service and the service received and how to make corrections to the service.

1.5 Public satisfaction and satisfaction Incentives

In general, satisfaction is feeling happy or disappointed someone, emerged after comparing the performance of 
the product with the desired result (Kotler, 2005). If performance meets expectations, then the customer will be satisfied. If performance exceeds expectations, then the customer will feel very satisfied. According to Daryanto and Ismanto Setyabudi (2014: 53) there are five main drivers of community satisfaction, namely, product quality, price, service quality, emotional factors, costs and convenience.

\section{Research Method}

The method used in this research is descriptive research with quantitative approach. The sampling technique used is incidental sampling with a sample size of 250 people who have received care in the district Sa'dan. Data collection techniques used questionnaires, observation and documentation. The data analysis technique used quantitative descriptive. Refers to the value perception Regulation of the Minister of Administrative Reform No. 14. of 2017 as the table below.

Perceived value, the value of Interval Interval Conversion Value, Service Quality and Performance Services Unit

\begin{tabular}{|c|c|c|c|l|}
\hline $\begin{array}{l}\text { Perception } \\
\text { Value }\end{array}$ & $\begin{array}{l}\text { Interval Value } \\
(\mathrm{Ni})\end{array}$ & $\begin{array}{l}\text { Interval Value Conversion } \\
(\mathrm{Nik})\end{array}$ & $\begin{array}{l}\text { Quality } \\
\text { Service } \\
(\mathrm{X})\end{array}$ & $\begin{array}{l}\text { of } \\
\text { Unit } \\
(\mathrm{Y})\end{array}$ \\
\hline 1 & $1,00-2,5996$ & $25,00-64,99$ & $\mathrm{D}$ & Not Good \\
\hline 2 & $2,60-3,064$ & $65,00-76,60$ & $\mathrm{C}$ & Poorly \\
\hline 3 & $3,0644-3,532$ & $76,61-88,30$ & $\mathrm{~B}$ & Good \\
\hline 4 & $3,532-4,00$ & $88,31-100,00$ & $\mathrm{~A}$ & Very Good \\
\hline
\end{tabular}

To know the expectations of the public to use the analysis of public services Importance Performance Analysis (IPA), which is also known as a quadrant analysis. This method was first introduced by James Martilla and analysis (Brandt, 2000: 34) with the aim to measure the relationship between consumer perceptions and priorities for improving the quality of products / services. IPA has the main function to display information relating to the factors of service according to the customer / service user influence satisfaction and loyalty, and the factors of service according to the consumer needs to be improved (improvement) because the current conditions are not satisfactory which consists of four quadrants.

This matrix is divided into four quadrants, with the following diagram:

Figure 1.

Importance-Performance Matrix

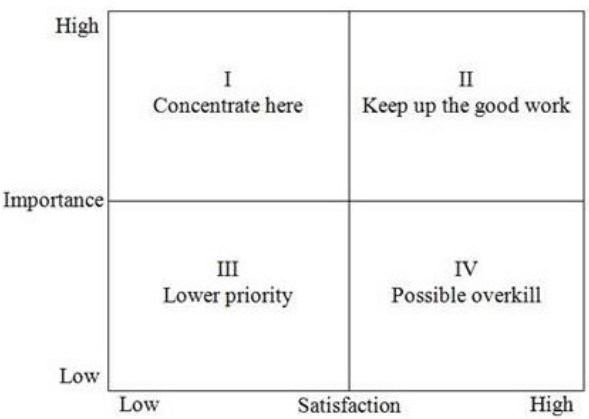

\section{Results and Discussion}

In this survey, there are nine (9) elements of the public service that will be studied at the District Office and will be described Community Satisfaction Index (CSI) of the Public Service at the District Office Sa'dan. Next will be described the analysis of public satisfaction rate (PSR), and the level of public expectation (LPE) against any element Sa'dan service at the District Office. Furthermore, the results of the analysis will be explained through diagram Importance Performance Analysis (IPA Diagram). Analysis of the IPA indicates the position and priority repairs of each service element in a diagram CSI value calculated by using the "weighted average value" of each service element. Analysis of the IPA indicates the position and priority repairs of each service element. The cumulative value of CSI in the Public Service in the district Sa'dan obtained at 75.59. If the value is converted in a range of assessment as mandated Regulation Of The Minister Of State Affairs For The Use Of State Apparatus And Bureaucratic Reform Number 14 of 2017 in the category Less Good. Scores for the category of Less Good value in the scale of measurement as set forth in Regulation Of The Minister Of State Affairs For The Use Of State Apparatus And Bureaucratic Reform Number 14 of 2017, ranged from 65.00 to 76.60. This means that the value of $\mathrm{C}$ obtained by the relatively high Sa'dan District Office. Service elements that get good ratings are element of competence waiter with CSI value 77.40 and behavioral components implementing with CSI value of 82.20. The service element that gots the lowest value is the element of Service 
Requirements with CSI value of 73.10. Followed by discipline service elements with CSI value of 74.00. The service specification product service element obtains CSI value 75.30, and the Service Procedure element with CSI value 75.20, only 1.41 points adrift from the lowest score in category B (76.61 - 88.30). Overall the value of CSI to public service in the District Office Sa'dan it can be concluded that the still low.

Next will be described an overview of the level of satisfaction, the level of public expectation towards every element of public service in the District Office Sa'dan, besides to determine the ratio between the level of Community Satisfaction (LCS) and Public Expectation Level (PEL) on public service elements seen from the GAP between these two things on every element of the service.

Requirements Analysis Services done by identifying all the existing requirements and assessing new requirements as needed on each activity and / or stages of service activities that directly relate to the substance of the type of service / product service. The relevant requirements and absolutely necessary for distandarisir services can be implemented optimally in accordance with the legislation in force. Completion Time Analysis Services Performed by identifying experiences, hopes recipient of the service, and the ability internal.Proses identification can be done through a survey to consider the effectiveness and efficiency of service. The time set in accordance with customer expectations and can be met by public service providers.

Service procedure is the ease of service provided to the community in terms of the simplicity of the service flow. the cumulative value of the CSI element Procedures for 75.20. The value if converted within the range assessment as mandated Regulation Of The Minister Of State Affairs For The Use Of State Apparatus And Bureaucratic Reform Number 14 of 2017 in the category Less Good. The CSI value indicates that most respondents rate element at the Sa'dan District Office Procedures less simple and less easily. the reason is the information on the conditions of service is very limited, making it difficult to find out what documents are required to be served. In fact, some respondents said they did not know whether there was a procedure that was passed to obtain services, even if there were officers who delivered service procedures, sometimes the explanation was different from other officers, so it often confused the community. In general, the average value of respondents' expectations of the element of Service Requirements is very high, which is equal to 3.76, compared to a satisfaction value of only 3.07. This condition causes GAP to be -0.75 . This shows that the majority of respondents rate the service element is very important, but the services received on the element is still relatively low.

For the District of Sa'dan government in an effort to improve the quality of public services should develop Standard Operating Procedures, and immediately organize Minimum Service Standards as a reference in the public service. The next step as a public service improvement strategy is to create policies that support the implementation of improved public services to the community. It is expected that with the issuance of policies on improving public services will further encourage the creation of quality of service that is effective, efficient and accountable.

Service time is the time limit required for a service provided to consumers. The time set from the time the application is submitted to the completion of the service including complaints must be related to the certainty of time in providing services in accordance with the stipulation of the length of service each time. the CSI value of the Service Time the Sa'dan District Office is 74.30. The value if converted within the range assessment as mandated Regulation Of The Minister Of State Affairs For The Use Of State Apparatus And Bureaucratic Reform Number 14 of 2017 in the category Less Good. In terms of satisfaction, respondents generally considered the service time in Sa'dan District Office to be less rapid, the reason respondents considered Service Time less fast was: (a) Service time were not in accordance with the written ones, especially the five-day work policy where services were opened until 16.00 (b) the presence of officers not in accordance with the time of commencement of the service that is informed, and many officers are rarely in the office, (c) the maintenance of the settlement documents has become a requirement of service requires a relatively long time, because the officers more attending traditional ceremonies, particularly in the month of May to December. The respondent's expectation of Service Time in general is very high, the average value of respondents' expectations of the Service Time element is very high, which is equal to 3.99 , while the satisfaction value is only 2.97 resulting in GAP of 1.02. This shows that the respondent's expectation of Service Time is still higher than the satisfaction value, so this element needs to be improved.

The discipline of service personnel, namely the sincerity of officers in providing services, especially to the consistency of work time according to applicable regulations. Cumulatively, the CSI value of the Discipline of Officer Sa'dan office is 74.00. The value if converted within the range assessment as mandated Regulation Of The Minister Of State Affairs For The Use Of State Apparatus And Bureaucratic Reform Number 14 of 2017 in the category Less Good. In other words, the sincerity and discipline of the Sa'dan District office officers were not satisfying the public in terms of public services. The reason for the respondent's opinion was that the time the Service was lacking was that the officers were not disciplined because: (a) Officers were often not in place, and were not on time when they promised to complete the service; (B) there are officers who late and often not in the office (c) not timely servicing schedule, and not in accordance with established (five working days, to 16.00), (D) 
there are officers who do not wear uniforms, and less neat appearance in the office. In terms of expectation, the average value of respondents 'expectations of the Officer Discipline element was 3.92, and when compared with the respondents' average satisfaction value of only 2.96, there was GAP of 0.96. The value of the GAP indicates that the Discipline element of the Servant Officers at the Sa'dan District Office was assessed by the respondents as very important, but the satisfaction was still very low. Therefore, the District government Sa'dan still need to improve elements of this discipline. Besides this, it will greatly affect the quality of service and the performance of government services overall Sa'dan district.

Specifications Product Service is the results of the service received in accordance with the conditions set. This relates to the fact that service delivery results in accordance with the specified service and free of technical errors, both in terms of writing the petition that has been filed earlier. CSI value element Specifications Product Services at the District Office Sadan at 75.30. These values are in the category of Less Good by Regulation Of The Minister Of State Affairs For The Use Of State Apparatus And Bureaucratic Reform Number 14 of 2017 in the category Less Good. In terms of satisfaction, in general respondents Specifications Product Services at the District Office Sa'dan less in accordance with the provisions set to an average value of 3.01. The reason respondents are less suitable is still frequent errors that require improvement. Expectations of respondents to the Service Specifications Product element is generally very high, average value of respondents' expectations of performance Specifications Product element 3.80, much larger than the average value of the satisfaction value of only 3.01. This condition occurs GAP cause of -0.79 , where it indicates that respondents' expectations of product performance specifications are very high, but the value of the satisfaction of the service is still lacking. Therefore, the Sa'dan District government needs to further improve its performance on this element so that community satisfaction increases.

Implementing competency is the ability to be possessed by the executor includes knowledge, expertise, skills and experience. CSI value Competence elements Sa'dan Services at the District Office at 77.40. The value if converted within the range assessment as mandated Regulation Of The Minister Of State Affairs For The Use Of State Apparatus And Bureaucratic Reform Number 14 of 2017 are in the Good category. Reliability here means the ability of service personnel, the level of expertise and the skills of personnel in providing or resolving service to customers or the public. The average value of respondents' satisfaction of 3.10 , in other words competence includes the knowledge, expertise, skills and experience Sa'dan waiter at the district office by a majority of respondents rated good.

The average value of respondents' expectations of elements of Waiter Competence is 3.92. This shows that the respondent's expectation of Waiter Competence is higher than the value of satisfaction. Further, that in an effort to improve the quality of public services, it is necessary to increase the capacity of manumur resources services, the Manumur Resources (MR) service apparatus has a strategic role as a driver (key leverage) of bureaucratic reform. Related to efforts to improve the quality of public services, it is necessary to be supported by reliable human resources (HR) services, as well as the availability of facilities and infrastructure including the support of Information Technology (IT). Therefore, the ministry of human resources as the key to the successful performance of public service organizations should receive primary attention in the improvement of service quality. Although generally competency waiter at the District Sa'dan by respondents generally good value, but there are still a few things to note that these achievements were maintained, even improved in the future. For that role as a sub-district leadership needs to consider some HR issues of public services that might be (constraints) the achievement of the organization's success include: (A) work ethic tends to maintain the status quo and will not accept any change (resistance to change); (B) a culture of risk aversion (not like risk); (C) the routine tasks and an overemphasis on formal accountability resulting in their rigid procedures / slow; (d) there is no system of incentives and disincentives for service officers who show high performance or vice versa; and (e) lack of human resource capabilities to analyze in making accurate service standards. (F) the potential problems, such as the conflicts between the political elite (elections), between communities, conflicts of interest between the executive and the legislature, $(\mathrm{g})$ the factual issues and the ability of the apparatus in the form of conditions of service, difficult to change the mindset and the high ego sectoral and conflicts of interest that still characterize the various institutions of government organizers. Implementing behavior is the attitude of officers in providing services that include courtesy, friendliness, respect and appreciation between officers and the community. cumulatively the CSI value of the element of Implementing Behavior in the Sa'dan District Office is 82.20. This value if converted in the range of assessments as mandated by Regulation Of The Minister Of State Affairs For The Use Of State Apparatus And Bureaucratic Reform Number 14 of 2017 is in the Good category. In terms of satisfaction, in general, respondents rate the Implementing Behavior at the District Office Sa'dan good, and very good, with a mean value of 3.29. Although the majority of respondents rated the element of Service Implementing Behavior in the Sa'dan District Office well, there were still a number of complaints submitted. Complaints such as: officers rarely give greetings and smiles, are not friendly, neatness / appearance of less officers, such as officers wearing sandals, putting food on the desk, not entering because they attend traditional ceremonies (tongkon), back home before working hours are over. In terms of expectations, all respondents rated 
the element of Implementing Behavior as very important, and important, with an average value of 3.92. This shows that the average value of respondents' expectations are higher than the average value of the satisfaction of the Implementing Behavioral elements.

It is important to pay attention to the behavior of the implementers in public services considering that HR employees working in public service units are not only required technical skills and skills and mastery of the underlying legislation, but more importantly mental attitude and good behavior are needed, friendly in serving honest, skillful and responsible.

Communities served will not care what the constraints and obstacles in work, will not care about the personal problems of employees, but they only care about what they need to be served well, easy, fast, cheap. Therefore, the element's behavior in the district Sa'dan implementers need to be increased considering the expectations of society in these agents is very high, and the judge is very important., And became a key word in improving the quality of public services.

element Complaints, Suggestions and Feedback cumulative value of these elements CSI at the District Office Sadan at 74.70. The value if converted within the range assessment as mandated Regulation Of The Minister Of State Affairs For The Use Of State Apparatus And Bureaucratic Reform Number 14 of 2017 in the category Less Good.

In terms of satisfaction, in general, respondents Complaints, Suggestions and Feedback at the district office Sa'dan less well, with a mean satisfaction score of 3.07. One of the complaints of the most widely presented respondents with regard to the element of Complaints, Suggestions and Feedback was no information or explanation from the officers on how to submit a complaint. Sa'dan District Government also has not had a complaint box. Besides the explanation of the officer on a complaint against the beating services - cumbersome and unclear. The average value of respondents' expectations of Complaints, Suggestions and Feedback 3.97, and the value of the satisfaction level of 2.99, this difference is causing the GAP between the average value of satisfaction with a mean value of -0.98 expectations. This value indicates the magnitude of the distance between satisfaction and expectations of respondents. In other words, respondents rate the Complaints, Suggestions and Feedback as an element essential services, but the services they receive from the element is still low, far from expectations. This indicates that the Service Complaints, Suggestions and Feedback needs to get serious attention from the Government of the District of Sa'dan.

Establishment of service complaints management is expected to accelerate the implementation of services which in turn can improve the quality of public services, so that satisfaction increases. Related to the management of complaints, there are some elements of service quality improvement is essential to be considered include: (a) the timeliness of services; (B) the accuracy of the service; (C) the courtesy and friendliness in providing services; (D) the responsibilities; (E) comprehensiveness; (F) the ease of getting services; $(\mathrm{G})$ variations of service models; and $(\mathrm{h})$ the convenience in obtaining service.

Furthermore, that the satisfaction of the people can be achieved when human resources involved directly in service can understand and appreciate and desire to provide a quality service. In order for HR services can actually support the improvement of quality of service, it is necessary to HR management service as well including the identification of the needs of human resources required in order to provision of services in accordance with service standards that have been established, particularly in relation to the competence and qualifications for each role will be played in each of the service process.

It was when importance in implementing management is staffing complaints according to the competency of being owned is one determinant of the success of the public service. In this connection, public service organizations should seek to do a search and staffing and implementing the concept of placing the right man on the right place, which was to determine the right person in every shape and type of services The process of selecting and placing HR should be done openly, by formulating policies as well as clear rules regarding all the requirements for job positions to be filled, as well as implement a standardized system to guide these activities. Some human resource criteria contributing to the improvement of service quality is the recruitment of competent in the field of public services which include the following: (a) commitments; (b) integrity; (c) responsibility; (D) competence and friendliness; (E) understand the needs of customers; (f) responsiveness and empathy; (G) and has the ethics and morality.

Services infrastructure can be defined as the process of cooperation utilization of all facilities and infrastructure to effectively and efficiently to provide professional service in the field of infrastructure and facilities in the process of effective and efficient services. Completeness of good infrastructure is very important in creating customer satisfaction. Infrastructure facilities and services elements referred to in this survey include the public perception of the quality of facilities and infrastructure owned by the District Government Sa'dan such as office space and equipment, working equipment, toilets, cleanliness and environmental safety. cumulatively the CSI value is 74.20. The value if converted within the range assessment as mandated Regulation Of The Minister Of State Affairs For The Use Of State Apparatus And Bureaucratic Reform Number 14 of 2017 in the category Less Good. Reasons respondents elements unfavorable Infrastructures, among others: (a) Equipment 
Sa'dan working at the District Office is very limited and the elderly, as limited a computer, printer, copier and other equipment, (b) less net office Condition and not neatly arranged, bathrooms and toilets are not clean, office roofs leak a lot, water is not smooth, (c) waiting rooms are not equipped with adequate chairs, file cabinets are very limited, and some other office equipment is old.

The average value of respondents' expectations of Service Facilities and Infrastructure is 3.96, while the average value of satisfaction is only 2.97. This condition causes GAP to occur at -0.99 , where this value indicates the magnitude of the distance between satisfaction and the expectations of respondents. In other words the respondents assessed the Service Facilities and Infrastructure as a very important element of service, but the services they received were still low, far from their expectations. This shows that Service Facilities and Infrastructure need to get serious attention from the Sa'dan District Government.

It should be admitted that the performance of public services were either not in spite of the availability of adequate physical aspects of service, such as the availability of services representif buildings, service facilities are sufficient, as well as support equipment has advanced technology. Lack of adequate service infrastructure causing the service to be inefficient, especially in terms of time. According to some employees at the District Office Sa'dan, many jobs often can not be completed on time due to limited facilities and equipment and inadequate support. It can give more indications in the District government public service performance indicated Sa'dan not maximized during this time also because of inadequate facilities and infrastructure services available. Furthermore Importance Performance Matrix analysis results are presented in the figure below:

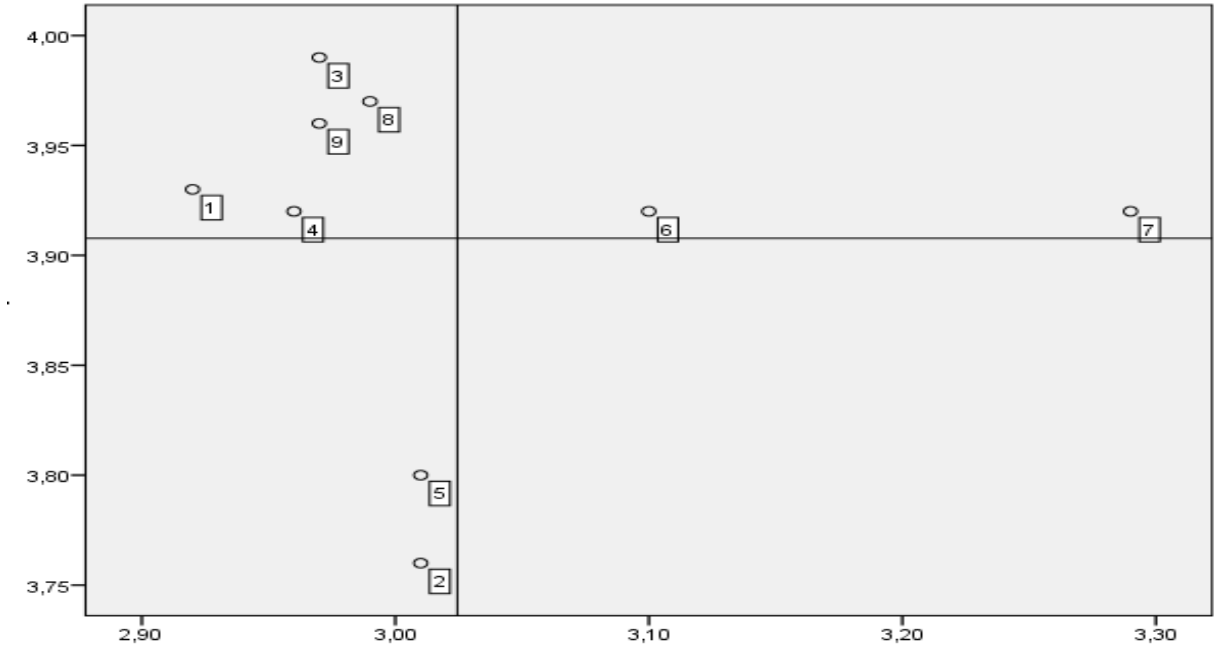

Based on the analysis of the diagram above, the priority of service improvement for the Sa'dan District Office is mapped based on the points in each quadrant, as follows: Quadrant I: Top priority for performance improvement (Performance Improvement) Some of the things that should have priority in service improvement are : Service Time (U3), Complaint Handling (U8), Facilities and Infrastructure (U9), Service Requirements (U1), Discipline (U4). Quadrant II: Keep achievement (Appreciation). In this quadrant, although there is still a gap between service quality and consumer expectations, but the respondents gave a high assessment of service quality for some of the things that feel important, so that the district office Sa'dan need to maintain the quality in the service that the Implementing Behavior (U7) and Competence Waiter (U6); Quadrant III: Low priority. Even though there is a gap between service quality and consumer expectations and the value of service quality is considered average, the variables mapped in Quadrant III have low priority for improvement, because consumer expectations for variables in this quadrant below average so rated as a low priority for improvement, namely: Product Specifications Services (U5), Procedures (U2); Quadrant IV: Exceeds Expectations In this quadrant, the assessment of service quality level above average and consumer expectations below average (low) so it is said that the quality of service has exceeded the expectations of consumers. Of the nine elements of service no one has entered in this quadrant.

\section{Conclusion}

Based on the analysis of Community Satisfaction Survey in the District of North Toraja district Sa'dan concluded that the performance of public services in the district Sa'dan generally considered unfavorable to the value of CSI 68.64. Of the nine elements of service, only two elements of both categories and selebinya are in the unfavorable category.

\section{References}

Arisman : 2017 : Mengukur Kepuasan Masyarakat dan Kualitas Pelayanan Publik, https://jakarta.kemenkumham.go.id/. 
Atep Adya Barata. (2003). Dasar-dasar Pelayanan Prima. Jakarta: Elex Media Komputindo

Daryanto dan Ismanto Setyobudi. Konsumen dan Pelayanan Prima, Cetakan pertama, Penerbit Gava Media, Yogyakarta, 2014

Fandy Tjiptono dan Anastasia Diana. (2003). Total Quality Management. Yogyakarta: Andi Offset.

Fandy Tjiptono. (2004). Manajemen Jasa. Yogyakarta: Andi Offset

Harbani Pasolong. (2010). Kepemimpinan Birokrasi. Bandung: CV Alfabeta

Kasmir. (2005). Etika Customer Service. Jakarta: PT Rajagrafindo Persada

Kotler, P. 2009. Manajemen Pemasaran (Terjemahan, Jilid 2). PT Indeks, Jakarta.

Ratminto dan Atik Septi Winarsih. (2005). Manajemen Pelayanan. Yogyakarta: Pustaka Pelajar.

Vincent, Gaspesz. (2011). Total Quality Management (untuk Praktisi Bisnis dan Industri). Bogor: Vinchristo Publication

Undang-Undang Nomor 25 tahun 2009 tentang Pelayanan Publik

Keputusan Menpan No.63/KEP/M. PAN/7/2003 tentang Pedoman Umum Penyelenggaraan Pelayanan Pulik.

Peraturan Menteri Pendayagunaan Aparatur Negara dan Reformasi Birokrasi Republik Indonesia Nomor 14 Tahun 2017 tentang Pedoman Penyusunan Survei Kepuasan Masyarakat Unit Penyelenggara Pelayanan Publik. 